\title{
Business Dominance among the Malays and Chinese in Malaysia from a Civilizational Perspectives
}

\author{
Wan Norhasniah Wan Husin
}

\begin{abstract}
The business sector can become a profitable venture and improve one's economic status remarkably. In Malaysia, the society's participation in business, whether in small enterprises like grocery, or large scale industries like construction, is largely controlled by the Chinese community than the Malays. Based on previous research, the domination by the Chinese is due to their assumed expertise in the field, as they are considered to possess shrewd business acumen inherited from their ancestors. This is different from the Malays whose economic activities were more concentrated on farming, livestock breeding, and petty trades compared to large scale business sectors. If there were Malays involved in big-scale businesses, they usually involve Malays from the upper crust of society. Therefore, the study aims to analyze the issue from a new perspective, by focusing on the effects of civilizational value on an ethnic's dominance in the business sector. From the study, it was found that both ethnics inherit contrasting civilizational values and the differences have affected the ethnics' achievement in the business sector. In order to achieve the study's objectives, the text analysis method was applied.
\end{abstract}

Index Terms - The Malay ethnic, the Chinese ethnic, business dominance, value system, civilizational perspective.

\section{INTRODUCTION}

The business is a sector that could yield high returns to anyone regardless of ethnic background. However, based on achievement, the success rate tends to differ from one ethnic to another. Among the factors that play a role in determining the success rate is culture, which determines the work ethics practiced by a community. The relation between cultural values and dominance in the economic sector was also proposed by Max Weber in his writing, The Protestant Ethics and the Spirit of Capitalism in 1905. Weber's findings had attracted the interest of various scholars to further study the impact of culture on business. According to him, culture does play a huge role in influencing work ethics and hence in determining an ethnic's success. To study the influence of cultural values in business, the study will focus on two major ethnics in Malaysia - the Malays and Chinese.

The contrast in work ethics between the Malays and Chinese from the civilizational perspective has not been investigated by any researcher. Previous research concentrated more on culture and business, and they were analyzed differently, without linking the possible connection between the two aspects. There were research that attempted to link the possible relations between business and culture,

Manuscript received February 20 2013; revised April 20, 2013.

Wan Norhasniah Wan Husin is with the National Defence University of Malaysia, Sungai Besi Camp, 57000 Kuala Lumpur, Malaysia (e-mail: hasniah@upnm. edu.my, hasni_wan02@yahoo.com). but did not present the effects of culture towards the conduct and action of a community, and the possibility of its impact on their success in controlling and managing businesses, education and application on relevant fields. It will bring you new like-minded researchers, fresh idea. It also provides a friendly platform for academic and application professionals from crossing fields to communication together. There are also researches that present the ethics of business and culture, or the impact of culture on business, but they do not study the impact of culture on business dominance by a community or ethnic. A study carried out by Md. Zabid Abdul Rashid and Jo Ann [1] Ho which was reported in 'Perceptions of Business Ethics in A Multicultural Community : The Case of Malaysia', analyzed the perspectives of the Malays, Chinese and Indians towards business ethics in Malaysia. They examined the similarities and differences between the three communities in conducting business dealings. However, no focus was given on the possible impact of culture on an ethnic's business practices. In Muhamad bin Ahmad's [2] thesis, 'The Influence of Culture on Malay Muslim Business Practice: A Case Study of Malaysia With Special Reference to the State of Kelantan Dar al-Naim', the Hindu-Islam, Malay-Islam culture in influencing the Malay community's practices when partaking in business at the Khadijah Market, Kelantan was debated on. However, the discussion did not centre on whether the cultural pattern affected the Malay community of the past, or those residing in other territories. The possibility of the Malays' ability or disability in dominating the field due to the influence of culture was also not examined. In the meantime, in Budaya dan Keusahawanan Cina di Malaysia, Chin Yee Wah [3] investigated the influence of the Chinese culture on business, but did not analyze the way the ethnic interact with other communities.

Therefore, it has been determined that the contrast between the work ethics embraced by the Chinese and Malay communities from the perspective of civilization have yet been explored by any scholar. The text analysis method was applied while researching for materials to fulfill the objectives of the study.

\section{A Civilizational Perspective}

A study from a civilizational perspectives debates upon the core values and basic principles entrenched within a civilization and culture. The core values refer to the internal values that form the conscience that controls the thoughts and actions of man. This concept is proposed by Lòpez [4] in her article titled The British Presence in the Malay World: a Meeting of Civilizational Traditions, in the Jurnal SARI. She 
refers to the value as the internalized filters and the action reflected is classified as below-level consciousness. It is the result of interaction reflected from the social norms and physical environment of a community, on whether the background is peaceful or chaotic caused by natural calamities or a ruler's cruelty. The core values are abstract in nature, and will only come to the fore when the ethnic interact with their surroundings. The basic principles, meanwhile, refer to the elements of religion, traditions, language, economy, politics, social, and arts that are the influential components that form the basic blocks of civilization and culture. The fundamental principles of a community are the elements that allow its people to interact with other ethnics, for they contain similar elements that could be shared. When the core values and basic principles combine, the identity and image of a community will be revealed. It is the core values that influence the actions of a community, and what set them apart from other ethnics. It is also through these values that prompt some ethnics to protect the basic principles that are considered their rightful heritage, in the form of language, religion, traditions, and economic dominance from being jeopardized, either through violence, or negotiations [11].

The manifestation of the core value is propositioned by Melko [5] who highlights the differences in the American society, as reflected in a game of volleyball between the Anglo-Saxon and Korean communities. For instance, the Anglo Saxons were more focused on the ability to win, so in order to defeat the other party, they created two teams; while the Koreans formed a circle, where they evaluated a player's wisdom in 'manipulating' his friends. This reveals that the stress upon certain basic principles differs between communities, for it all depends on one's needs and orientation.

In contrast, the Malays place emphasis on the values of religion, politics, language, and customs that shape the core principles of their civilization [6]. Meanwhile, the Chinese are resolute in safeguarding their language, education, culture and economy, which they would not hesitate to proffer their unyielding support to any party that could aid them in protecting the values. The Chinese ethnocentric nature was born out of their allegiance towards their heritage in the form of language, culture and family values which was prevalent in mainland China [6]. For the purpose of this study, research will focus on the economic principles, by analyzing the work ethics observed by the Malay and Chinese businessmen in managing and expanding their companies.

Thus, to meet the objectives of the study, civilizational perspectives will focus on the aspect of culture and its influence on the work ethics of both ethnics. It includes the role of the value system, influence of traditions inherited from the forefathers, whether from the context of political or economic relations involving individuals from different or similar social classes, and the role of family ties and the society of an ethnic.

\section{A. The Malay's Culture}

From the aspect of culture, the Malays are a people borne out of traditions, and stress upon the importance of Islam in their life. From previous research, it was determined that the Malays' value system, traditions and work ethics are based on the core values of budi-Islam, which led to the birth of a people that are tolerant, cooperative and respectful of others. The suitability of the Malays' budi core values and Islam had founded the ground for the Malays' customs and traditions to be shaped according to the values of Islam [7]. Islam's integral aspects influenced the Malays' core values, as the principles are similar in nature - to guarantee peace in society and protect the devotees from any form of harm. As a result, it effortlessly led the Malays to embrace Islam in droves, as the conscience, thoughts, actions and traditions observed by the community are intertwined with that of Islam [4].

The incorporation of the values was further reinforced by the Malay Peninsula's strategic location, which was bestowed from any peril of natural disasters, or even threats from the Malay rulers presiding over the sacred, rich land. The surroundings had directly influenced the community's complacent attitude, as they preferred to enjoy pursuing leisure than use their ample time on hard labour [8]. Even if the attitude was viewed negatively by some quarters, a study showed that the community's laissez-faire and cautious nature gave them the upper hand to execute any given task perfectly, and even govern their territory effectively. Therefore, it is not surprising that the values are fused into the mannerisms and actions adopted by the Malays when performing business transactions. The values, without any doubt, are prevalent in guiding them in executing their job functions and in managing their business deals [1].

From the aspect of culture, in the olden days, business ownership among the Malays was then based on one's social status. The domain of trading and agricultural was reserved exclusively for the aristocrats, as it was crucial to ensure that the clout to rule remained in their clutch. The trade sector was in the hands of the upper crust of society since the era of the Srivijaya Empire and continued in the succeeding kingdoms in the Malay Peninsula and Sumatra [9]. The peasants were mainly unencumbered from getting involved in the business or trade sector, as their major breadwinning occupation was to either till the land as farmers or cast their skills as fishermen. In fact, the Malays were not inspired to accumulate riches as they were bequeathed with an environment that was peaceful and aplenty with provisions, that they saw no dire need for wealth. The situation continues to the present day, as the only scenario that has changed is that the political domain of the country is now no longer based on the feudal political system, but is under the governance of the Constitutional Monarchy and Democratic Parliament. Thus, the economic and political controls of the nation are no longer under the jurisdiction of the Kings, but have shifted into the hands of the Malays, without any discrimination on their social class or standing in society. Even though the trade sector involves the participation of people from all walks of life, but it is an undeniable fact that the authority remains in the powers-that-be. However, the major concern among scholars is why the staying power of the Malay businessmen is not as resilient as the Chinese traders.

\section{B. The Chinese Culture}

The Chinese's way of thinking is ideally based on their reverence towards their elders, known as filial piety, as 
observed by Moore [10]. The notion is replicated into all aspects of their life, which cause them to place importance on loyalty towards the family, hence the stress upon kinship [10] Their ethnocentric nature was borne out of the various hardships that they had to endure, as many natural calamities befell them, apart from the many clashes between clans or tribes due to differences of dialect and region, and the atrocity of the Emperors. The deplorable state of affairs was widespread in the South of China region, which prompted many of its residents to migrate from mainland China to flee the ill-fated living conditions [11]. Thus, their conduct was the result of a socialization process that stressed upon filial piety, and as it thrived in the society's relations, it resulted in ethnocentricity. Meanwhile, being involved in business activities is a norm for the Chinese, as it is an esteemed tradition common in mainland China. It is their main source of income, especially since the majority of the immigrants were traders (Huashang) [12].

When conducting business, the Chinese's work ethics are tightly bound to value systems that stress on discipline, family ties, and the 'Chinese-links'. As business is their tradition inherited from their forefathers, they hardly face any obstacle to excel in the field. Their tireless efforts, discipline, diligence, filial piety and ethnocentrism had allowed the business sector to flourish among the community. For the Chinese, one's religious beliefs, be it Buddhism, Confucius, Christian or Islam are not of extreme importance, as religion is not the main orientation for the Chinese community's spiritual fulfillment [12].

Hence, business, for the Chinese community, is not affiliated to any faith. Thus the question on everyone's mind is, what are the factors that contribute to the success enjoyed by the Chinese in the business sector? Does the Chinese's business acumen stem from the value systems and business principles inherited from their forefathers?

\section{Business PARTiCiPATION AMONG THE MALAYS AND CHINESE IN MALAYSIA}

Malaysia is a multi-racial country made up by various ethnic communities. The plural society is primarily made up of the Malays, the natives of the land that form the majority of the population, the ethnic Chinese, the second largest ethnic group, who are originally immigrants that hail from mainland China. The swift rise in their population occurred during the British occupation, starting in 1875, as they were needed to fill up the vacuum for jobs direly required in the mining, agriculture, and business sectors. When performing daily interactions, the Malays and Chinese inherit their own identities and uphold their cultural attributes like their rituals, family ties, work ethics, value systems and religion. As a result of the contrast from cultural traditions and civilizations, it was observed that the community's actions and work ethics in executing their daily activities also differed [13].

In the Malays' hierarchy system, since the Melaka empire era, the business sector was controlled by the elite class, while the commoners were involved in petty trades, farming and fishing. Under the Malay feudal political system, the trade sector was primarily dominated by the Malay aristocrats, like the Sultan, palace chieftains and the affluent merchants [9].

In the system, the Malay elites' domination in business continued until the New Economic Policy was introduced in 1970 , with a transition in economic clout, to the hands of royalty, politicians and their business partners. The Malay commoners' participation in the sector was not significant as business was not considered as a major source of income for them. The stance was further accentuated with the Malays' culture of modesty, that they do not place substantial importance on the accumulation of wealth, thus they are not enthusiastic to pursue success in business, and are easily contented with what they have [9].

The situation continues until the post-independence period with an estimated minimal $2.4 \%$ of Malays involved in business enterprises compared to the Chinese's overwhelming $97.6 \%$ participation at the end of 1970 [13]. To improve the Malays' economic standing, the government launched the New Economic Policy (NEP) in 1970 after the racial riot that erupted between the Malays and Chinese on 13 May 1969. Even though the aim of the NEP's implementation was to increase the Malays' business equity in the nation to $30 \%$ by the year of 1990 , but in reality, the target was not fully achieved. According to a Malay Non-Government Organization (NGO) Peneraju Agenda Bumiputera (TERAJU), the Malays' economic stake in 2008 was only $21.9 \%$, and that the Malay traders were only concentrated on small enterprises that had minor impact on the nation's Gross Domestic Product (GDP) like construction, as $65 \%$ of the businesses yielded annual returns lower than RM 250000.00 [14]. Even if the government had established various agencies to assist the Malays in business like Majlis Amanah Rakyat (MARA-1966), where they could procure funds, entrepreneurial training, business premises, and higher education opportunities, but the achievement is still far from exemplary. Thus, even though there are a number of Malay individuals who have succeeded immensely in the business world, but the achievement is not as great as the Chinese's feats, mainly due to the work ethics and perception towards business observed by the community.

For the Chinese immigrants, the major influence in the business connection among them is their devotion towards the values of filial piety. Their dedication ensures that the trust and camaraderie were instilled among them, hence all techniques and deals were secured by them, and do not fall into the hands of others. Their loyalty towards family also guaranteed that businesses that can no longer be managed by the father or elders will be continued by a filial son. In one such case in Hong Kong, a father had called his son home from abroad to continue running the family business. The son's loyalty and devotion to the family ensured his return, and in the process, closed down his clinic in Los Angeles to perform his due obligations as a faithful son [8].

It is this kind of connection that allows a Chinese family to expand their business interests to various nooks and corners in Southeast Asia. They would appoint members of the family like a son or daughter to head operations in a number of locations across the region, such as in Manila, Malaysia, Singapore, Hong Kong or Bangkok. In a larger-scale network, a 'bamboo network' will then rely on their connection with other Chinese in different territories. Even if there was the 
possibility of encountering contrasting political ideologies or dialects, but still, shared traditional similarities between them ensure that they would work out the differences in order to accomplish success [15] The tie is further reinforced with the establishment of the Chinese Guilds and other Chinese Halls or Associations [16], the so-called 'guardians and custodians' of the Chinese community's interests.

The culture was preserved and reinforced when the Chinese community spread their wings in new territories like Malaysia, but prospered in a new facet. In mainland China, they were mainly linked through blood relations, but in newly-explored regions, their pragmatism changed to the flourishing of the sense of kinship. If an individual hails from a different clan or background, camaraderie among them is then formed through the elements of trust, hard work and prudence [11].

The emergence of the Chinese ethnic presence in the Malay Peninsula started during the British occupation in order to fill the employment void needed in the farming and mining sectors. With their long-held traditions, each Chinese faction separated by dialect and place of origin began to explore Malaya's economic sector whether in agriculture, farming, fisheries or mining]. Business domination became more prominent with the support from the Chinese kinship, which came in the form of capital funding from early Chinese settlers who had resided in the region since 3 A.D., like the Straits Chinese and Peranakan Chinese. They explored prospects in the business, industry, and other economic sectors which then led to the Chinese ethnic's dominance in Malaya. By the $19^{\text {th }}$ Century, the tin mining industry developed further when the British introduced new techniques, spurred by the urgency to accommodate Europe's industrial needs. Once British consolidated its command over the Federated Malay States, the tin mining industry's control changed into the hands of the Chinese traders, and European capitalists. Meanwhile, from the aspect of land ownership for rubber plantation, once the British revoked the traditional system into British law, land entitlement among the Chinese swelled abruptly [9].

By inheriting the business shrewdness from their ancestors, coupled with support provided by the British and Malay leaders, the Chinese traders succeeded in gaining a stronghold on the nation's economic sector. This is showcased through the mushrooming of various corporations and enterprises, such as the Federal Flour spearheaded by Robert Kuok and the Tan Chong Motors owned by the Tan family [16]. The wealth and power accorded to the Chinese, however, remained within the Chinese circle, and no Chinese entity or even MCA members are willing to assist non-Chinese individuals to attain the same success as them. The Chinese business prowess continues to flourish until the present day, and at the expense of the indigenous Malays, has supplanted them into the wealthiest community in Malaysia.

\section{CONCLUSION}

The study shows that there is a strong link between the civilizational as well as cultural values and the mechanism of conducting business between the Malays and the Chinese.
The ability of the Chinese to sustain their business due to the strong networking among themselves and the practicing of 'Guangxi' (forming personal relationship) facilitates the business in term of opportunities and cost of doing business since it is based on trust rather than contract. The purpose of 'Guangxi' is to nurture relationship to create harmony as preached in the teaching of Confucius. Currently, the Malays not only are lacking in term of skill and late comer in this field, but they also do not have a cohesive group to help each other and their linkage to parties outside the country is in significant as compared to Chinese bamboo networks that have linkages with fellow ethnic throughout ASEAN Countries, Hong Kong and Taiwan. This disparity in the ability between these two ethnics groups in a way justifies the effort by the government to provide incentives to the Malay business community to enhance their activities prowess in business.

\section{ACKNOWLEDGEMENT}

We wish to offer our gratitude for the opportunity extended by Yapiem to present the paper at this conference.

\section{REFERENCES}

[1] Md. Z. A. Rashid and J. A. Ho, "Perceptions of business ethics in a multicultural community: the case of Malaysia," Journal of Business Ethics, Springer, vol. 43, no. 1-2, pp. 75-87, March 2003.

[2] M. Ahmad, "The Influence of Culture on Malay Muslim Business Practice: A Case Study of Malaysia with Special Reference to the State of Kelantan Dar al-Naim," PhD Thesis, The University of Birmingham, 2009.

[3] C. Y. Whah, Budaya dan Keusahawanan Cina, Bangi: Penerbit UKM, 2003.

[4] L. C. Carolina, "The British Presence in the Malay World: A Meeting of Civilizational Traditions," in Journal SARI, vol. 19, Bangi: Institut Alam dan Tamadun Melayu Universiti Kebangsaan Malaysia, 2001.

[5] M. Melko, The Nature of Civilizations, Boston: Porter Sargent Pulisher, 1969.

[6] A. B. Shamsul, "Texts and Collective Memories: The Construction of 'Chinese' and 'Chineseness' from the Perspective of a Malay," in Ethnics and Nation-Building in Southeast Asia: The Case of The Ethnic Chinese, Leo Suryadinata (ed). Singapore: Institute of Southeast Asian Studies, pp. 124, 2004

[7] W. A. Kadir, Tradisi dan Perubahan Norma dan Nilai di Kalangan Orang-orang Melayu, Petaling Jaya: Masfami Enterprise, 2000.

[8] W. N. W. Husin, Peradaban dan Perkauman di Malaysia: Hubungan Etnik Melayu-Cina, Universiti Malaya, 2012.

[9] A. Omar and S. Salleh, "Perubahan Entiti Melayu: Antara Ketuanan dan Tuntutan Global dalam Kerangka Wawasan Ekonomi Politik," in Dinamika Bangsa Melayu Menongkah Arus Globalisasi, Bangi: Universiti Kebangsaan Malaysia, 2004.

[10] C. A. Moore, "Introduction: the humanistic Chinese mind," The Chinese Mind, Essentials of Chinese Philosophy and Culture, Honolulu: The University Press of Hawai, 1967.

[11] T. T. Tan, Your Chinese Roots: The Overseas Chinese Story, Singapore: Times Books International, pp. 30-40, 1986.

[12] G. W. Wang, "The Study of Chinese Identities in Southeast Asia," China and The Chinese Overseas, Times Academic Press, pp. 3-11; 179-183, 1991

[13] M. Mohamad, the Malay Dilemma, Singapore: Times Books International, 1982.

[14] Bernama, Teraju reveals current state of Bumiputera corporate equity ownership, 26 November 2011.

[15] M. Weidenbaum and S. Hughes, The bamboo network: how expatriate chinese entrepreneurs are creating a new economic power in Asia, New York: Martin Kessler Books The Free Press, 1966.

[16] E. T. Gomez, "Political Business in Malaysia: Party Factionalism, Corporate Development, and Economic Crisis," in Political business in East Asia, London: Routledge, 2002. 


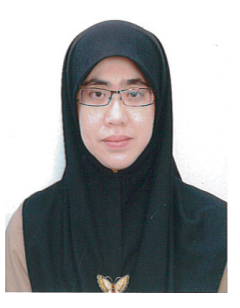

Wan Norhasniah Wan Husin was born in Besut Terengganu, Malaysia on 22 February 1972. She obtained her Bachelor Degree in Islamic studies from International Islamic University in 1996, and her Master Degree in Islamic politics in University of Malaya, Malaysia in 2002. Then she continued her study at $\mathrm{PhD}$ level in ethnic politics at University of Malaya and graduated in 2010 Currently she is an associate professor at National Defence University of Malaysia. Her major research areas are ethnic politics, Islamic criminal laws, and civilization and culture.

She has authored a number of papers published in international as well as local journals. Among the papers published in 2011 are 'Budi-Islam: It's Role in The Construction of Malay Identity in Malaysia, Nation-Building and 1Malaysia Concept: Ethnic Relations Challenges in The Educational Fields and An Analysis of Ethnic Relations between the Malay and Chinese
Communities in Malaysia from Civilizational Perspectives: Language and Education Experiences. All the above papers were published by International Journal of Humanities and Social Sciences. So far she has authored two books, which are 'Peradaban dan Perkauman di Malaysia; Hubungan etnik Melayu-Cina' (Civilization and Communalism in Malaysian: Ethnic Relations of The Malays and Chinese), and 'Hukuman Bunuh ke atas Pengedar Dadah berdasarkan Siyasah Syari'yyah' (Death Penalty to Drug Traffickers According to Siyasah Syariyyah). Both were published by University of Malaya publication. Dr Wan Norhasniah Wan Husin also involves in professional activities. She is a member of Scientific and Technical Committee \& Editorial Review Board on Human and Social Science (International). She also a National Committee member for course of Islamic and Asian Civilization, and she has been the member of Social Science Association of Malaysian since 2009. 